\title{
Effect of Vernalization and Fungicidal Seed Treatment on Yield and Quality of Wheat (Triticum aestivum L.)
}

\author{
Parikshit Singh*, A. L. Jatav, Poonam Singh, Abhishekh Singh, \\ Sagar Kumar Sharma and Udai Singh Chaudhary
}

\author{
Department of Seed Science and Technology, C.S. Azad University of Agriculture and \\ Technology, Kanpur - 208002(UP), India \\ *Corresponding author
}

\section{A B S T R A C T}

The field experiments were conducted at New Dairy Farm, Kalyanpur, and seed quality parameters were assessed in the Seed Testing Laboratory of Department of Seed Science

\section{Keywords}

Vernalization, Fungicidal seed treatment.

Article Info

Accepted:

04 July 2017

Available Online:

10 September 2017 and Technology, C. S. Azad University of Agriculture and Technology, Kanpur during Rabi season of 2013-14 and 2014-15. Experiment was conducted on Wheat variety, Shatabdi (K-307) to evaluate the effect of Vernalization and Fungicidal seed treatment. The effects of seed treatment and vernalization duration found significant for all the characters during both the years and pooled analysis except for germination (under open field), leaf size, plant height, number of seeds per plant, No. of seed per ear head, seed yield per plant in pooled analysis. The maximum germination, number of tillers per plant, leaf size (length $\times$ width) and plant height were recorded with treatment $F_{2}$ (With fungicide (Vitavax@2.5g/kg seed) during both the years and pooled analysis. The interaction effects of seed treatment and vernalization duration found non-significant for all the characters during both the years and pooled analysis except for germination (under open field), leaf size, plant height, number of seeds per plant, No of seed per ear head, seed yield per plant in pooled analysis.

\section{Introduction}

Botanically wheat is known as Triticum aestivum L. belongs to the family Poaceae. It is a hexaploid i.e.6x $(2 n)=42$ crop having 7 basic chromosome number. Wheat is a goldcolored grass that grows to approximately 1 $\mathrm{m}$. in height, bearing clusters of sharp bristles and hard grains at its tip. This subspecies has a long, cylinder spike which is somewhat flattened. Spikelet's are 2 to 5 flowered, relatively far apart on the stem and nearly erect. Awns either lacking or less than half an inch long. Stem centers are generally hollow but may be pithy.
Globally, wheat contributes approximately 30 per cent of the total cereal production and about 60 per cent of daily protein requirement and more calories to world diet. Wheat contains 12.6-14 g protein, 1.5-1.9 g fat, 68$71 \mathrm{~g}$ carbohydrate, $12.2 \mathrm{~g}$ dietary fibre, 360 kcal energy, $39 \mathrm{mg}$ calcium, $239 \mathrm{mg}$ magnesium, $842 \mathrm{mg}$ phosphorus, $892 \mathrm{mg}$ potassium, $12.29 \mathrm{mg}$ zinc and $6.26 \mathrm{mg}$ of iron, 17-20 per cent of the daily requirement in human body. Grown all over the world, wheat covers more of the earth's surface than any other cereal crops, however, it takes more 
land space than other cereals, based on a three years average it is only the third-largest cereal crop, behind maize and rice. In terms of production, China is the largest producer of wheat followed by India in the second position. The India's share in world wheat production is 13.53 per cent. India is likely to produce 95.85 million tonnes of wheat during 2013-14, compared to 93.31 million tonnes last year (ICAR, 2015).

Vernalization is the low temperature treatment given to water soaked seeds, slightly germinated seeds, or seedlings to hasten the time of flowering of plants that will develop from them. Chouard (1960) has defined vernalization as the "acquisition or acceleration of the ability to flower by a chilling treatment."

In the history of agriculture farmers observed a traditional distinction between "winter cereals," whose seeds require chilling and "spring cereals," whose seed can be sown in spring and flower soon thereafter (Chouard, 1960). The word "Vernalization" is translation of "Jarovization," a word coined by Trofim Lysenko to describe a chilling process, he used to make the seed of winter cereals behave like spring cereals (Chouard, 1960). Scientists had also discussed how some plants needed cold temperatures to flower as early as the $18^{\text {th }}$ century, with the German plant physiologist Gustav Gassner often mentioned for his 1918 paper (Chouard, 1960).

Early researches on vernalization focused on plant physiology, the increasing availability of molecular biology has made it possible to unravel its underlying mechanisms (Amasino, 2004). For example, longer days as well as cold temperatures are required for winter wheat plants to go from the vegetative to the reproductive state. The three interacting genes are called VRN1, VRN2 and FT (VRN3), (Trevaskis, 2007).
In some variety, vernalization serves to shorten time to flower by shortening the vegetative period of plant, which helps in production of more than one crop in a year. By sowing winter crop in spring season, plant can be protected from freezing injury due to very low winter temperature. Long summer requiring plant (e.g. cotton, maize) can now be grown in temperate areas with the short summer requiring plant.

There are many techniques available to increase the production of wheat but they are costly. So the farmers have compulsion to adopt it, and consequently the cost of wheat production goes high. But the vernalization technique is very easy and less costly as compared to other to enhance the yield of the crop therefore this topic has been taken for study.

\section{Material and Methods}

The field experiments were conducted at New Dairy Farm, Kalyanpur, Kanpur and seed quality parameters were assessed in the Seed Testing Laboratory of Department of Seed Science and Technology, C. S. Azad University of Agriculture and Technology, Kanpur during Rabi season of 2013-14 and 2014-15 to assess the seed yield and quality parameters of Wheat variety Shatabdi (K307). The experiment was laid out in Factorial RBD. The crop was sown on 5 December 2013, using the seed rate of $100 \mathrm{~kg} / \mathrm{ha}$. A recommended dose of NPK 120:60:40 kg/ha were applied. There were 9 treatment combinations with Four vernalization durations viz. 15 days $\left(\mathrm{V}_{1}\right), 20$ days $\left(\mathrm{V}_{2}\right), 25$ days $\left(\mathrm{V}_{3}\right), 30$ days $\left(\mathrm{V}_{4}\right) @ 5^{0} \mathrm{C}$ temperature, 2 doses of Fungicidal seed treatment viz., without fungicide $\left(\mathrm{F}_{1}\right)$ and with fungicide $\left(\mathrm{F}_{2}\right)$ (vitavax @2.5g/kg seed) along with control. One hoeing and weeding was done 30 days after sowing (DAS). On 10 randomly selected plants, yield contributing and morphophysiological characters were recorded from 
each plot i.e. Germination (under field conditions), Number of tiller/ plant, Leaf size (length x width), No. of ear head/ plant, Plant height, Days to $50 \%$ flowering, Number of days taken to attain physiological maturity, No. of seeds/plant, No. of seeds/ear head, Seed yield/plant.

\section{Results and Discussion}

\section{Effect of fungicidal treatment}

Seed treatment with fungicide and without fungicide did not change significantly all the characters except germination under field condition, number of seeds per plant, in pooled analysis. This was mainly due to the fungicide not had significant differences for the characters.

The maximum germination, number of tillers per plant, leaf size (length $\times$ width) plant height were recorded with treatment $\mathrm{F}_{2}$ (With fungicide (Vitavax@2.5g/kg seed) followed by $F_{1}$ (without seed treatment) and minimum in control during both the years and pooled analysis.

The yield attributes viz., number of ear head per plant, number of seeds per plant, number of seeds per ear head and seed yield per plant were highest recorded with treatment $F_{2}$ (With fungicide (Vitavax@ $2.5 \mathrm{~g} / \mathrm{kg}$ seed) followed by $F_{1}$ (without seed treatment) and minimum in control during both the years and pooled analysis. The maturity traits did not influenced significantly by seed treatment. The maximum days taken to $50 \%$ flowering, days taken to physiological maturity were observed in $\mathrm{F}_{2}$ With fungicide (Vitavax @ $2.5 \mathrm{~g} / \mathrm{kg}$ seed) $82.27,133.67$ days followed by $\mathrm{F}_{1}$ (without seed treatment) 82.17 days 133.46 days and minimum in control during both the years and pooled analysis. Similar results were also reported by Boldizsar et al., (2011), Robertson et al., (1996), Ribeiro et al., (2009), Amasino (2004).

\section{Effect of vernalization}

The duration of vernalization significantly influenced germination under field condition. Maximum germination (1980.63) was recorded with $\mathrm{V}_{4}$ (duration of vernalization for 30 days) which was significantly superior over control (1790.38), $\mathrm{V}_{1}$ (1921.63), $\mathrm{V}_{2}$ (1928.44) and $\mathrm{V}_{3}(1946.31)$.

Minimum germination (under open field) is recorded in control during both the years and pooled analysis. The number of tillers per plant, influenced non-significantly due to duration of vernalization, maximum number of tillers per plant was observed with the vernalization treatment $\mathrm{V}_{4} \quad(10.33)$ and minimum number of tillers per plant in control during both the years and pooled analysis.

Duration of vernalization was found nonsignificant for leaf size; maximum leaf size was observed with the vernalization treatment $\mathrm{V}_{3}$ (41.57) and minimum in control (39.04).

Similarly, duration of vernalization significantly influenced plant height, maximum plant height recorded with the exposure of vernalization for 30 days which was significantly superior over control, $\mathrm{V}_{1}$ and $\mathrm{V}_{2}$ and at par with exposure of vernalization for 25 days and minimum was recorded in control during both the years and pooled analysis. Furthermore, the duration of vernalization was found non-significant for number of ear head per plant, maximum number of ear head per plant was observed with the vernalization treatment $\mathrm{V}_{4}$ (duration of vernalization 30 days) 9.70 during both the years and pooled analysis. Maximum number of seeds per plant was registered highest with the vernalization treatment $\mathrm{V}_{4}$ (duration of vernalization 30 days) 513.32. 
Table.1 Effect of vernalization and fungicidal seed treatment on germination, No. of tillers/plant, Leaf size of wheat

\begin{tabular}{|c|c|c|c|c|c|c|c|c|c|c|c|c|c|c|c|c|c|}
\hline \multicolumn{6}{|c|}{ Germination (under field conditions) } & \multicolumn{6}{|c|}{ Number of tillers/ plant } & \multicolumn{6}{|c|}{ Leaf size (length $\mathrm{x}$ width) } \\
\hline \multicolumn{6}{|c|}{ Duration of Treatment in Days $(\mathbf{P})$} & \multicolumn{6}{|c|}{ Duration of Treatment in Days $(\mathbf{P})$} & \multicolumn{6}{|c|}{ Duration of Treatment in Days $(\mathbf{P})$} \\
\hline Treatments & $15\left(V_{1}\right)$ & $20\left(V_{2}\right)$ & $25\left(V_{3}\right)$ & $30\left(\mathbf{V}_{4}\right)$ & Mean & Treatments & $\begin{array}{l}15 \\
\left(V_{1}\right)\end{array}$ & $\begin{array}{l}\mathbf{2 0} \\
\left(\mathbf{V}_{2}\right)\end{array}$ & $\begin{array}{l}25 \\
\left(V_{3}\right)\end{array}$ & $\begin{array}{l}30 \\
\left(V_{4}\right)\end{array}$ & Mean & Treatments & \begin{tabular}{|l|}
15 \\
$\left(V_{1}\right)$
\end{tabular} & $\begin{array}{l}\mathbf{2 0} \\
\left(\mathbf{V}_{2}\right)\end{array}$ & $\begin{array}{l}25 \\
\left(V_{3}\right)\end{array}$ & \begin{tabular}{|l}
$\mathbf{3 0}$ \\
$\left(\mathbf{V}_{4}\right)$
\end{tabular} & Mean \\
\hline $\mathbf{F}_{1}$ & 1920.75 & 1926.37 & 1942.75 & 1980.38 & 1942.56 & $\mathbf{F}_{1}$ & 9.60 & 9.70 & 10.11 & 10.21 & 9.90 & $\mathbf{F}_{1}$ & 40.94 & 41.48 & 41.05 & 40.91 & 41.09 \\
\hline $\mathbf{F}_{2}$ & 1922.50 & 1930.50 & 1949.88 & 1980.88 & 1945.94 & $\mathbf{F}_{2}$ & 9.65 & 10.04 & 10.08 & 10.45 & 10.06 & $\mathbf{F}_{2}$ & 40.89 & 41.37 & 42.08 & 40.61 & 41.24 \\
\hline Mean & 1921.63 & 1928.44 & 1946.31 & 1980.63 & 1944.25 & Mean & 9.63 & 9.87 & $\mathbf{1 0 . 1 0}$ & $\mathbf{1 0 . 3 3}$ & 9.98 & Mean & 40.92 & 41.43 & 41.57 & \multirow[t]{2}{*}{40.76} & 41.17 \\
\hline Control & & & & & 1790.38 & Control & \multicolumn{5}{|r|}{6.70} & Control & & & & & 39.04 \\
\hline & $\mathbf{F}$ & $\mathbf{V}$ & $F \times V$ & & $\begin{array}{l}\text { Cont. Vs } \\
\text { Treat. }\end{array}$ & $\mathbf{F}$ & \multicolumn{2}{|c|}{$\mathbf{V}$} & $F \times V$ & \multicolumn{2}{|r|}{$\begin{array}{c}\text { Cont. Vs } \\
\text { Treat. }\end{array}$} & $\mathbf{F}$ & \multicolumn{2}{|l|}{ V } & $F \times V$ & \multicolumn{2}{|c|}{$\begin{array}{l}\text { Cont. Vs } \\
\text { Treat. }\end{array}$} \\
\hline C.D. & 4.78 & 6.75 & 9.55 & & 7.27 & N.S. & \multicolumn{2}{|c|}{ N.S. } & N.S. & & 0,57 & N.S. & \multicolumn{2}{|c|}{0.52} & 0.74 & \multicolumn{2}{|r|}{0.56} \\
\hline S.E(d) & 2.37 & 3.35 & 4.73 & & 3.60 & 0.19 & \multicolumn{2}{|c|}{0.26} & 0.37 & & 0.28 & 0.18 & \multicolumn{2}{|c|}{0.26} & 0.37 & \multicolumn{2}{|r|}{0.28} \\
\hline S.E(m) & - & - & - & & - & - & - & ( & & - & & - & - & & - & \multicolumn{2}{|r|}{ - } \\
\hline
\end{tabular}

Table.2 Effect of vernalization and fungicidal seed treatment on No. of ear head/ plant, plant height, Days to 50\% flowering of wheat

\begin{tabular}{|c|c|c|c|c|c|c|c|c|c|c|c|c|c|c|c|c|c|}
\hline \multicolumn{6}{|c|}{ No of ear head/ plant } & \multicolumn{6}{|c|}{ Plant height } & \multicolumn{6}{|c|}{ Days to $50 \%$ flowering } \\
\hline \multicolumn{6}{|c|}{ Duration of Treatment in days $(\mathbf{P})$} & \multicolumn{6}{|c|}{ Duration of Treatment in days $(\mathbf{P})$} & \multicolumn{6}{|c|}{ Duration of Treatment in days $(\mathbf{P})$} \\
\hline Days & $15\left(V_{1}\right)$ & $20\left(V_{2}\right)$ & $25\left(V_{3}\right)$ & $30\left(V_{4}\right)$ & Mean & Days & $15\left(V_{1}\right)$ & $\begin{array}{c}\mathbf{2 0} \\
\left(\mathbf{V}_{2}\right)\end{array}$ & $\begin{array}{c}25 \\
\left(\mathbf{V}_{3}\right)\end{array}$ & $\begin{array}{c}30 \\
\left(\mathbf{V}_{4}\right)\end{array}$ & Mean & Days & $15\left(V_{1}\right)$ & $\begin{array}{c}20 \\
\left(\mathbf{V}_{2}\right)\end{array}$ & $\begin{array}{c}25 \\
\left(\mathbf{V}_{3}\right)\end{array}$ & $\begin{array}{c}30 \\
\left(\mathbf{V}_{4}\right)\end{array}$ & Mean \\
\hline $\mathbf{F}_{1}$ & 8.75 & 9.16 & 9.22 & 9.66 & 9.20 & $\mathbf{F}_{1}$ & 89.32 & 96.42 & 104.02 & 104.41 & 98.54 & $\mathbf{F}_{1}$ & 78.99 & 81.16 & 83.65 & 84.90 & 82.17 \\
\hline $\mathbf{F}_{2}$ & 8.91 & 8.93 & 9.36 & 9.74 & 9.23 & $\mathbf{F}_{2}$ & 91.54 & 95.91 & 103.65 & 104.58 & 98.92 & $\mathbf{F}_{2}$ & 78.80 & 81.82 & 83.62 & 84.84 & 82.27 \\
\hline Mean & 8.83 & 9.04 & 9.29 & 9.70 & 9.22 & Mean & 90.43 & 98.16 & 103.83 & 104.50 & 98.73 & Mean & 78.89 & 81.49 & 83.64 & 84.87 & 82.22 \\
\hline Control & & & & & 6.31 & Control & & & & & 79.09 & Control & & & & & 73.48 \\
\hline & $\mathbf{F}$ & $\mathbf{V}$ & $\mathbf{F x}$ & & $\begin{array}{l}\text { Cont. Vs } \\
\text { Treat. }\end{array}$ & $\mathbf{F}$ & $\mathbf{V}$ & & $\mathbf{F x V}$ & & $\begin{array}{l}\text { ont. Vs } \\
\text { Treat. }\end{array}$ & $\mathbf{F}$ & $\mathbf{V}$ & & $F \times V$ & & $\begin{array}{l}\text { ont. Vs } \\
\text { Treat. }\end{array}$ \\
\hline CD & N.S. & 0.43 & N.S & & 0.46 & N.S. & 1.29 & & 1.82 & & 1.95 & N.S. & 1.47 & & N.S. & & 2.23 \\
\hline SE(d) & 0.15 & 0.21 & 0.30 & & 0.23 & 0.45 & 0.64 & & 0.90 & & 0.97 & 0.52 & 0.73 & & 1.03 & & 1.10 \\
\hline $\mathrm{SE}(\mathrm{m})$ & - & - & - & & - & - & - & & - & & - & - & - & & - & & - \\
\hline
\end{tabular}


Table.3 Effect of vernalization and fungicidal seed treatment on Number of days taken to attain physiological maturity,

No of seeds/plant, Seed yield/plant of wheat

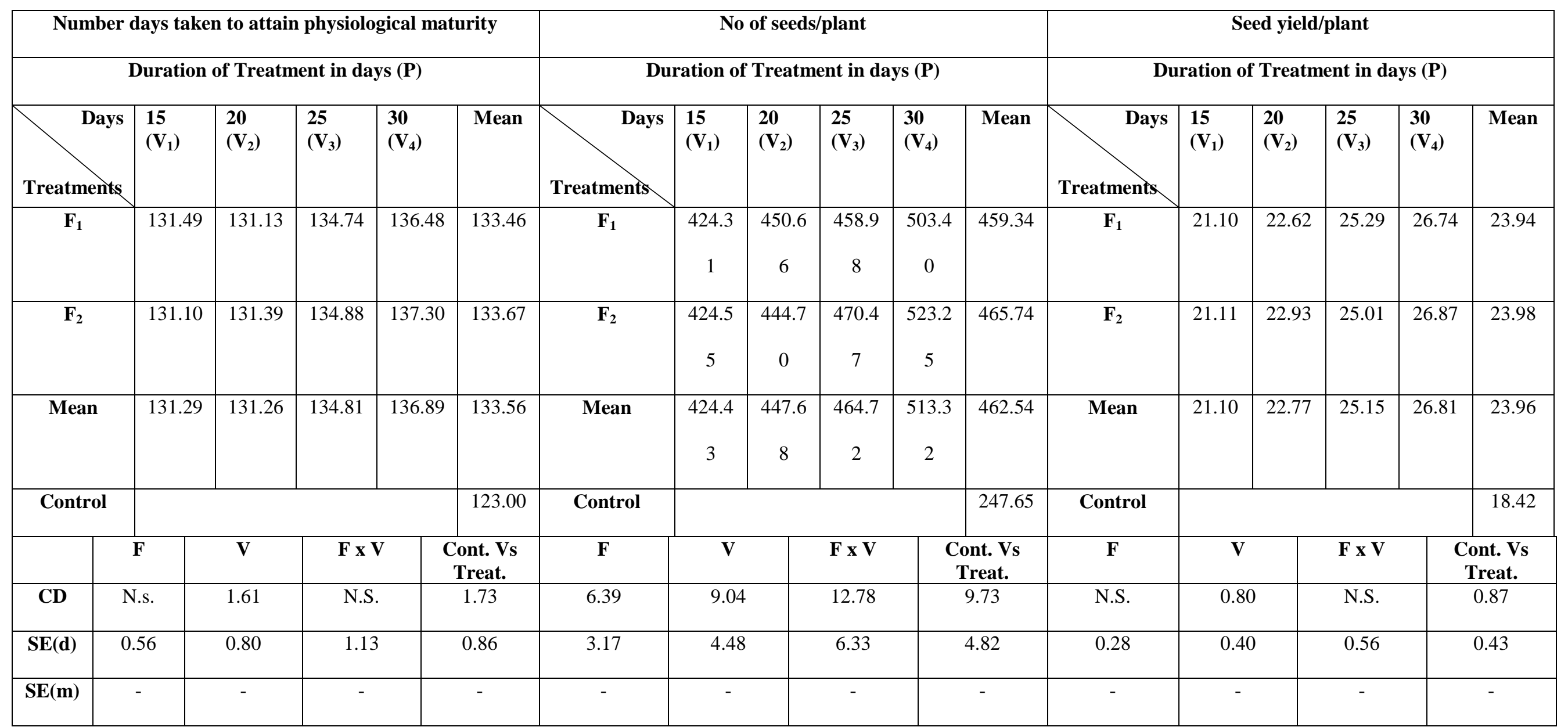


Similarly, duration of vernalization significantly influenced seed yield per plant which was recorded highest with the vernalization treatment $\mathrm{V}_{4}$ (duration of vernalization 30 days) and minimum seed yield was obtained from control during both the years and pooled analysis. Similar results were also reported by Nishiura et al., (2014), Jing Juan et al., (2014), Weir et al., (1984), Ablaza et al., (2010).

Henceforth, the present investigation indicate that the duration of vernalization affects the plant growth and yield attributes significantly which reveals that the increasing of vernalization duration also increased the plant height, other growth parameters and yield attributes such as number of seeds per plant and seed yield per plant.

Seed treatment with fungicide and without fungicide did not change significantly all the parameters except germination under field condition, number of seeds per plant, in pooled analysis. This was mainly due to the fungicide not had significant differences for the characters.

The maximum germination, number of tillers per plant, leaf size (length $\times$ width) plant height were recorded with treatment $F_{2}$ (With fungicide (Vitavax@2.5g/kg seed) followed by $F_{1}$ (without seed treatment) and minimum in control during both the years and pooled analysis (Tables 1-3).

The present investigation indicate that the duration of vernalization affects the plant growth and yield attributes significantly which reveals that the increasing of vernalization duration also increased the plant height other growth parameters and yield attributes as number seeds per plant, number of ear head per plant and seed yield per plant. Better survival as well as better growth of plants after vernalization may be attributed to their improved winter hardiness suggesting that vernalization and winter hardiness ability of a genotype may be governed by the same or closely linked genes.

The interaction effects of seed treatment and vernalization duration found non-significant for all the characters during both the years and pooled analysis except germination (under open field), leaf size, plant height and number of seeds per plant, in pooled analysis.

The seed treatment with fungicide Vitavax@2.5g/kg seed found better for almost of the characters it concluded that the treatment of seeds with fungicide improve the growth and yield attributes in wheat.

\section{Acknowledgement}

This study has been supported by Department of Seed Science and Technology, C.S. Azad University of Agriculture and Technology, Kanpur.

\section{References}

Ablaza, J. D., Ishikawa, K., Mori, M., Shirai, H. and Yasutake, D. 2010.Vernalization effect for seed of late sowing cultivation in wheat (Triticum aestivum L.). Jour of Food, - Agric.-and Environment, 8(2-2): 651-653.

Amasino, R., 2004. Vernalization, Competence, and the epigenetic Memory of Winter Wheat. Plant Cell (American Society of Plant Biologists); 16(10) 2553-2559.

Anonymous, 2015. Agricultural Statistics at a Glance 2014. Directorate of Economics and Statistics, Department of Agriculture and Cooperation, Ministry of Agriculture, Government of India. Pp. 89

Boldizsar, A., Gulyas, Z., Carrera, D., Soltesz, A., Vashegyi, I., Szalai, G., 
Galiba, D. G. Koesy and G. Boldizsar. 2011. Redox regulation of cold acclimatization and vernalization in wheat. Acta-Biological-Szeg; 55(1):6366.

Chouard, P., 1966.Vernalization and its relations to dormancy. Annul. Rev. Plant Physiol. 11: 191-238.

Chujo, H., 1966. The effect of diurnal variation of temperature on vernalization in wheat. Journal of crop science society of Japan 35: 187-194.

Jing Juan, Z., Dell, B., Biddulph, B., Khan, N.,YunJi, X.,Hao, H. and Appels, R. 2014Springer, Dordrecht, Netherlands, Euphytica, , 198(3), 439-454.

Nishiura, A., Kazama, Y., Abe, T., Mizuno, N., Nasuda, S., and Murai, K. 2014.Japanese Society of Breeding, Tokyo, Japan, Breeding Science, 64(3), 213-221.
Ribeiro, T. L. P., Cunha, G. R., Pires, J. L. and Pasinato, A. 2009.Phonological response of Brazilian wheat cultivars to vernalization and photoperiod. PesAgro-Bras., 44(11): 1383-1390.

Robertson, M. J., Brooking, I. R., and Ritchies, J. T. 1996.Temperature response of vernalization in wheat: molding the effect on the final number of main stem leaves. Annals of Botany; 78: 371-381.

Trevaskis, B., Megan, N., and Elizabeth, S. 2007. The molecular basis of vernalization- induced flowering in cereal. Trends in Plant Science (Elsevier) 12(8): 352-357.

Weir, A. H., Bragg, P. L., Porter, J. R. and Rayaer, J. H. 1984. A winter wheat stimulation model without water or nutrient limitations. Journal of Agri. Sci., Cambridge; 102: 371-382.

\section{How to cite this article:}

Parikshit Singh, A.L. Jatav, Poonam Singh, Abhishekh Singh, Sagar Kumar Sharma and Udai Singh Chaudhary. 2017. Effect of Vernalization and Fungicidal Seed Treatment on Yield and Quality of Wheat (Triticum aestivum L.). Int.J.Curr.Microbiol.App.Sci. 6(9): 20-26. doi: https://doi.org/10.20546/ijcmas.2017.609.002 